\title{
INVESTIGATING THE USE OF PROJECT-BASED LEARNING IN ENHANCING INDONESIAN UNIVERSITY STUDENTS' CULTURAL KNOWLEDGE
}

\author{
Lewinna Aguskin $^{1 *}$; Maryani \\ ${ }^{1,2}$ Faculty of Languages and Cultures, Maranatha Christian University \\ Jl. Prof. drg. Surya Sumantri, M.P.H. No. 65, Bandung 40164, Indonesia \\ ${ }^{1}$ winna_ch@yahoo.com; ${ }^{2}$ marumaryani@gmail.com
}

Received: $25^{\text {th }}$ August 2020/ Revised: $31^{\text {st }}$ August 2020/ Accepted: $26^{\text {th }}$ October 2020

\begin{abstract}
How to Cite: Aguskin, L., \& Maryani. (2020). Investigating the use of project-based learning in enhancing Indonesian university students' cultural knowledge. Humaniora, 11(3), 203-210.

https://doi.org/10.21512/humaniora.v11i3.6645
\end{abstract}

\begin{abstract}
The research investigated the use of email interview to develop the critical thinking and creativity of the university students in American culture classes. The students conducted email interview with Americans for group project and had group discussion with the Americans. Learning culture was an integral part of learning a language, which was crucial for the Englsih as a Foreign Language (EFL) learners to develop their awareness and understanding of the rich and dynamic cultural aspects of the target language. Thus, providing cultural experiences through project-based learning (PBL) would be motivating for the language learners in exploring the target culture. The data were collected from students' open-ended online questionnaire and observation notes, which contain students' interview result and their presentation slides. Descriptive statistics and thematic analysis were used in analyzing the data. The findings indicate that the use of project-based approach is helpful to enhance the students' understanding and critical thinking skills. Moreover, it is found that the students 'positive attitude has increased due to the use of PBL. They are more critical towards the cultural phenomenon since their communication skill has developed.
\end{abstract}

Keywords: project-based learning, cultural knowledge, university students

\section{INTRODUCTION}

Teaching American culture to Indonesian university students is challenging. It is not easy to teach basic American beliefs, values, and character traits which influence significantly on various aspects of American life. Maryani and Aguskin (2019) have stated that it is possibly difficult for Indonesian students to study American culture from textbooks only. In addition, they do not have easy access to meet the Americans in the society where they live. Thus, there is a crucial need for non-native teachers of foreign language to overcome the knowledge gap for Indonesian students in learning American culture. This can be done by applying student-centered learning in the classroom which allows students to experience meaningful and authentic learning experience from
English native speakers. In other words, it is necessary to apply the principles of Project-Based Learning (PBL) due to the fact PBL provides the students with the opportunities for exploration, investigation, and recognition of their world for real-life experiences (Thomas in Kean \& Kwe, 2014) Kean and Kwe (2014) argue that incorporating PBL for teaching culture is effective not only for students but also foreign language teachers. The students are able to explore and discover knowledge based on their needs and interest without too much dependency on the teacher.

There are some important principles related to PBL and the use of project work. PBL is defined as a systematic teaching method that engages students in learning knowledge and skills through an extended inquiry process structured upon complex, authentic questions and carefully designed products and 
tasks (Markham in Maida, 2011). Moreover, Bell (2010) states that utilizing PBL enables students to develop twenty-first-century skills as they learn to communicate, negotiate, and collaborate with their partners in accomplishing the project. Bell (2010) believes that PBL is an innovative approach which leads the learners to gain deeper understanding and develop communication skills. Moreover, the students are motivated to be life-long, independent, creative, cooperative learners as well as developing their personal growth (Thuan, 2018).

In order to implement PBL through project work, Stoller (2014) has identified several key principles of project work. First, the focus of project work is on content learning and related to interesting real-world topics. Second, the learning process is students-centered in which the roles of the teacher is as facilitator and guide. Third, the students work in small groups to accomplish a task in cooperative environment. Fourth, doing the project enables the students to develop authentic integrated skills which are similar to real-life tasks. Fifth, the learning entails process and product orientation in which the students are required to submit the final product (such as oral presentation, poster session, or report) which can be shared with others. Sixth, the outcome of the learning process promotes the motivation, independence, and abilities of the students. Obviously, using project work potentially creates meaningful and creative learning experience for the students including culture learning which involves critical and analytical skills.

There are several studies related to the use of project-based learning. First, Anuyahong (2015) has conducted a project-based research to 60 undergraduate students at Thai-Nichi Institute of Technology in Bangkok, Thailand. The purposes of this research are to discover the usage of projectbased approach to improve the participants' English speaking skill and to find the participants' perceptions related to the use of project-based research. It uses five instruments, namely lesson plans, project evaluation form, English speaking test, student's self-assessment form, and satisfaction questionnaire (Anuyahong, 2015). Besides, t-test is used to discover the comparison of participants' speaking achievement pre and post the project-based approach. The result shows that there is a significant higher participants' speaking achievement after the project-based approach, and that the participants feel satisfied after using project-based approach.

Second, Ballantyne (2016) has done a research on the use of project-based learning approach in order to develop 30 university students' writing skills in Khon Kaen University, Thailand. The researcher aims to discover the effects of project-based learning approach to students' writing skill and their attitudes towards the use of project-based learning. Four instruments, namely pre and post-test, lesson plan, teacher's notes, and questionnaire are used in the research. The results shows that the participants' writing skills improve as they also enjoy the learning process using project-based approach. Likewise, the use of PBL for writing classes are also evident in the studies by Deveci (2018). The study indicates that first-year students in an Emirati university have positive collaborative writing experience in a PBL class. They are able to develop English and teamwork skills in active learning environment.

Third, Parker (2020) has investigated the attitudes of the university students towards PBL in learning Spanish as a second language in United States. The result implies that the students have positive attitude because they can apply the knowledge and have a better understanding as well as developing their language competence. Moreover, they can explore their creativity in the experiential learning for realworld application of the language.

Fourth, due to lack of opportunities for authentic communication in English, the university students in Ukraine participates in cross-cultural projects to improve their English and cross-cultural competence. The application of PBL in this cross-cultural setting is helpful for the students to develop their communication skills, cross-cultural competence, and motivation. Thus, the cross-cultural language environment can close the language gap in the classes and real life (Syzenko \& Diachkova, 2020).

There has also been some research related to PBL in Indonesia. First, Mali (2016) shows that the use of PBL in Creative Writing and Second Language Acquisition classes for the university students promotes the participation of students in learning and the innovative practices of the teachers. Furthermore, using PBL is helpful for mirroring real-life tasks where the students are active to take part in planning, designing, and collaborating with their classmates in groups. In addition, utilizing PBL proves to be a valuable learning experience for the students to integrate the technology in doing their projects. Similarly, Irawati (2015) indicates that the use of cultural PBL for Indonesian university students of English Department is influential to improve the academic writing of the students in terms of content and vocabulary. However, the PBL practice is less effective in terms of organization and language use. Nevertheless, the students and the lecturer show positive learning attitude in the application of PBL.

Second, Pratiwi et al. (2018) conduct a directed project based learning research to 46 eight-grader students in Uram Jaya Lebong District, Indonesia. They learn English in class, particularly about invitation card, descriptive text, and greeting card. This research aims to develop a learning model called Directed-Project Based Learning (DPjBL) to improve the students' English skills. The data are obtained from test, observation, questionnaire, and interview. The results shows DPjBL works effectively in the class as the students are considered to be more motivated to learn, express their ideas, and develop their confidence.

Third, the research of Utami, Tyas, \& Mustika (2019) present the use of project-based learning method to teach English for university students 
of marketing management major. A commercial advertisement video is analyzed to teach the language of promotion. The students are assigned to create a promotional video as their project. This study proves that project-based learning can be utilized to enhance the learning goals which entail English and the use of technology in industrial revolution 4.0.

It is apparent that there have been several studies regarding the use of project-based learning to improve students' English speaking and writing skills. However, to the best of our knowledge, there is little research on the use of project-based learning to enhance the Indonesian students' foreign cultural understanding. Accordingly, this research is conducted to fill the gap of using project-based research for undergraduate students in learning American culture in a private university in Bandung, West Java.

The research attempts to answer the two research questions. First, it aims at investigating to what extent the use of email interview for projectbased learning helps to enhance the Indonesian students' understanding of American culture. Second, it explores the students' attitudes towards the use of email interview for project-based learning in enhancing their understanding of American culture.

Th research aims to discover the effects of using email interview for project-based learning to enhance the university students' understanding of American culture and also their attitudes towards the use of project-based learning. The research will give insights about the effects of using project-based learning for any lecturers, especially who teaches foreign culture.
Furthermore, the research is to explore the perspectives of the students in the use of PBL for learning culture.

\section{METHODS}

A qualitative research is used to answer the research questions. Open-ended online questionnaire is used to collect various students' perceptions regarding the use of project-based learning to enhance the students' cultural understanding. Moreover, the research also uses data collected from the students' projects.

The respondents are 29 undergraduate students of a private university in Indonesia. These students (male and female) come from two classes of American Culture. Their ages are between 18 and 21 years old.

To answer the research questions, it uses two types of instruments. The first one is the observation notes containing the detailed information related to the students' participation in project-based learning approach. These include the students' Power Point slides and the interview result. The second instrument is the online open-ended questionnaire that contains the students' perceptions and attitudes towards the project-based learning that they have experienced.

Descriptive statistics is used to analyze the data from questionnaire, whereas the data from the observation notes are coded and analyzed using thematic analysis. Table 1 shows the steps of implementing project-based learning which follows Ballantyne's (2016) research.

Table 1 The Steps of PBL Implementation

\begin{tabular}{|c|c|}
\hline The Steps of Implementing PBL & Classroom Activities \\
\hline 1. Starting the Project & $\begin{array}{l}\text { 1. The lecturer explains the project to the class. } \\
\text { 2. The students are divided into } 6 \text { groups in each class. Each group is } \\
\text { assigned one topic from the textbook to discuss. } \\
\text { 3. Each group is given the email address of the American to be interviewed } \\
\text { via email. Each group gets one American to be asked about several } \\
\text { questions regarding the topic discussed in the textbook. }\end{array}$ \\
\hline 2. Developing the Project & $\begin{array}{l}\text { 1. Each group send an introductory email to the American to explain } \\
\text { about their project for the class. } \\
\text { 2. After getting the reply from the American, each group send an email } \\
\text { containing 5-10 questions for the American. } \\
\text { 3. Receiving the American's answers for the questions in the previous } \\
\text { email, the students in each group analyze the answers together. } \\
\text { 4. Each member of the group discusses the result of the online interview } \\
\text { and compares them with the points stated in their textbook. } \\
\text { 5. Each group compiles the ideas and created a Power Point presentation } \\
\text { file. }\end{array}$ \\
\hline 3. Reporting to the Class & $\begin{array}{l}\text { 1. Each group presents their Power Point slides in the class } \\
\text { 2. Other students ask several questions regarding the presentation }\end{array}$ \\
\hline 4. Assessing the Project & $\begin{array}{l}\text { 1. Each group submit the Power Point file and the email interview result } \\
\text { to the lecturer. } \\
\text { 2. The lecturer assesses each member of the group. The presentation } \\
\text { rubric is used to assess the content of the presentation and the quality } \\
\text { of each individual presentation. }\end{array}$ \\
\hline
\end{tabular}




\section{RESULTS AND DISCUSSIONS}

This section presents the analysis of the first research question about how the use of email interview for project-based learning helps to enhance the Indonesian students' understanding of American culture. The data is based on the students' responses in the questionnaire and the result of their group presentation.

The results show that from 29 responses, 21 $(72,4 \%)$ students state they gain more knowledge and understanding related to American culture such as their favorite sports, education system, tradition, ethnic and racial diversity as they have said:

S1: "We learn how different their education is from ours. We gain new knowledge."

S2: "Knowing about American culture from someone who has experienced it."

Moreover, 10 (34,5\%) students explain that they have new experiences of emailing and communicating with Americans. As stated by some students:

S3: "I can communicate with foreigner, which I rarely done before. And I can know details information about American because I asked to the American himself."

S4: "I got the feeling of proudness as I have successfully email a new person."

The findings also show that the students could learn new information which are different and more detailed than what are written in the textbook. They are able to compare the situations in US and in Indonesia. The information is related to education system, the use of technology, health issue, hobbies, lifestyle, and American values. Regarding the topic of education, some students explain that:

S5: "American education is different from Indonesian education."

S6: "Students in America do part time job while taking lessons to pay their students loan."
S7: "The education system. It is said that private school teaches about more religious value."

In terms of leisure time, the students have mentioned that:

S8: "Lifestyle of Americans is more healthy than previous days. Some news that we just know from American."

S9: "I now know about health more, that Americans have higher rate on obesity."

S10: "Americans love to watch sport events with their friends and families." state that:

Referring to American values, several students

S11: "American people are hard workers and independent. They do not rely on others."

S12: "Not all Americans agree with the American value (in general)."

In short, interviewing the Americans by email is helpful for the students and give positive impacts, as one student underline that:

S13: "It motivates me to study harder as the American."

The result of their interview and analysis is presented in the class as a group presentation. Thus, the final product of PBL is shared with the teacher and other students. The teacher and students can give comments and questions regarding their analysis. In the presentation, they clearly explain the new or important things they learn from the email interview. Besides, the interview allows them to compare the ideas in the textbook to the result of the interview. Each group discusses one topic related to education, leisure time, or ethnic and racial diversity. The main points that they learn are presented in Table 2.

The findings indicate that emailing the

Table 2 The Result of Group Project Analysis

\begin{tabular}{|c|c|}
\hline Topics & The Results of Group Project Analysis Based on the Email Interview and Textbook \\
\hline \multirow[t]{4}{*}{ Education } & $\begin{array}{l}\text { - There is still inequality and racism as challenges, people with high dedication still working } \\
\text { hard for the sake of better future. }\end{array}$ \\
\hline & $\begin{array}{l}\text { - There is an anti-expert, anti-intellectual strain in American culture that can make it difficult } \\
\text { to gather support and interest in education. }\end{array}$ \\
\hline & $\begin{array}{l}\text { We learn about the classification of professional and non-professional job and the factors } \\
\text { of people getting high salary. }\end{array}$ \\
\hline & $\begin{array}{l}\text { - He has witnessed teachers and students display behaviors indicative of racism but rare and } \\
\text { usually very implicit or underhanded. }\end{array}$ \\
\hline
\end{tabular}




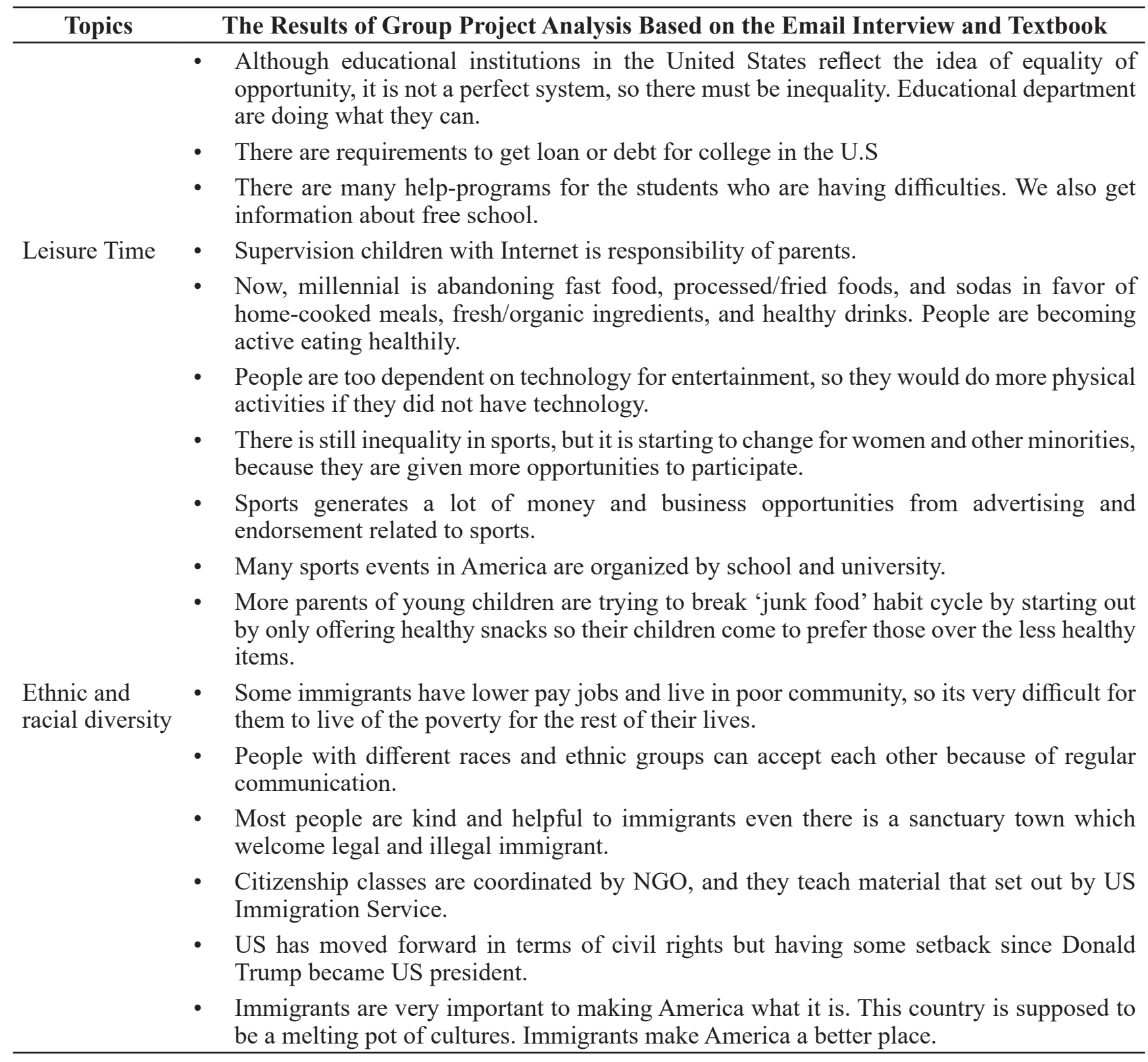

Americans is helpful for the students to obtain detailed and updated information regarding the current situation in the United States in terms of education, spending leisure time, and ethnic racial diversity. It means that the use of PBL allows the students to learn the culture content related to real-world topics. They can expand their knowledge related to American culture from the Americans since their knowledge is not limited to what they read in the textbook by having authentic communication with the Americans. Interestingly, by working in a small group, the students can also develop authentic integrated skills such as critical thinking, communication, writing, and analytical skills by cooperating with each other to achieve the task together. Obviously, the use of PBL are motivating the students to have meaningful learning experience. It can also be seen from the perspectives of the students due to the use of email interview.
Regarding the second research question, this section describes the students' attitudes towards the use of email interview for project-based learning in enhancing their understanding of American culture. The answer to the research question is gained from the students' responses to two sub-questions which are about: 1) the students' responses after doing the online interview project, 2) whether the students will keep in touch with the American that they interviewed or not and why.

The findings of the first sub-question show that from 29 responses, $26(89,7 \%)$ students shared their positive attitudes, whereas $3(10,3 \%)$ of them showed their negative attitudes after doing the email interview project. The sample of the students' positive and negative attitudes can be seen in Table 3 .

The students' positive attitudes can be seen from their statements which show their interest in 
interviewing the Americans by emails. The students did not only get the insights about American culture reading the textbook or browsing the internet, but they also gain a lot of new information from the Americans themselves through emails. However, the negative attitudes can be seen from three students' reactions towards the online interview. Two of them feel uncomfortable due to the slow response from the American and one student admits that asking the American to do interview face to face is more fun than by emails.

The findings of the second sub-question show that from 29 responses, $11(37,9 \%)$ students share their positive attitudes, $17(58,6 \%)$ of them shows their negative attitudes, and $1(3,5 \%)$ of them is being neutral. The sample of the students' positive, negative, and neutral attitudes can be seen in Table 4.

The students' positive attitudes can be seen from their statements which show their interest in keeping in touch with the American that they have interviewed by email. The reasons for their being positive are: 1) the Americans turn out to be nice when being interviewed, 2) the students obtain the recent information about America and its society, 3) the students feel that it is good to connect with the American as he/she has helped them with the class project, and 4) the students think that it is fun to do email interview. The students' neutral attitude can be seen from his/her answer that due

Table 3 The Attitudes of the Students in Using Email Interview for PBL

POSITIVE NEGATIVE

- I find it interesting because it is kinda rare to receive some information through the American

Not really great because not all of our questions himself, so it feels like special.

- I feel informed, because interviewing the - Quite worried because the American took long to Americans give me a lot of new information. respond.

- We learned so much about the difference between - I think it is more fun if we can talk Face to Face Americans and Indonesians.

- I know more information from the native American directly. It is better to ask American than just browsing or read the book to know America.

- It feels nice because I can know more about America from the real American and I do not really have to hold back in asking the questions.

Table 4 The Samples of the Students' Attitudes toward Maintaining the Relations with the Americans

\begin{tabular}{|c|c|c|}
\hline \multicolumn{3}{|c|}{ The Students' Interest in Keeping in Touch with the Americans } \\
\hline YES & NOT SURE & NO \\
\hline $\begin{array}{l}\text { Sure, because Dr. } \mathrm{X} \text { is a very nice } \\
\text { person. }\end{array}$ & $\begin{array}{l}\text { Maybe. This semester is busy so if } \\
\text { I have time maybe I would like to } \\
\text { contact her. }\end{array}$ & $\begin{array}{l}\text { Maybe no, because I tend to be } \\
\text { awkward in building relationship } \\
\text { with native speaker especially I } \\
\text { never meet them personally. }\end{array}$ \\
\hline $\begin{array}{l}\text { Yes, so I can get the most update } \\
\text { information about what happened in } \\
\text { America. }\end{array}$ & & $\begin{array}{l}\text { No, I am afraid if we get in touch, I } \\
\text { will make them feel uncomfortable. } \\
\text { I also do not want to disturb them, } \\
\text { but maybe email them for anything } \\
\text { that related to the lessons is okay. }\end{array}$ \\
\hline $\begin{array}{l}\text { Yes, because she has help us doing } \\
\text { our assignment. }\end{array}$ & & $\begin{array}{l}\text { No, because honestly personally } \\
\text { I do not use email that much to } \\
\text { communicate. }\end{array}$ \\
\hline Yes, because it is fun. & & $\begin{array}{l}\text { No, because we already got the } \\
\text { answer for the project and we } \\
\text { already thanked him. }\end{array}$ \\
\hline $\begin{array}{l}\text { Yes. I want to know more about } \\
\text { America, maybe in another topics. } \\
\text { And I hope the American helps me } \\
\text { to know more about America. }\end{array}$ & & $\begin{array}{l}\text { No, because I have already } \\
\text { email him asking if he wanted to } \\
\text { know anything about Indonesian } \\
\text { education, but he did not reply. }\end{array}$ \\
\hline
\end{tabular}


to his/her being busy this semester, keeping in touch with the American is not his/her priority. However, the students' negative attitudes can be seen from their being uninterested to continue their communication with the Americans due to these reasons: 1) feeling awkward and uncomfortable to keep in touch, 2) not getting used to write emails to communicate, 3 ) the emails are only for class purpose, and 4) no more responses from the American.

The finding of the research is in line with the research of Kean and Kwe (2014) which underlines that utilizing PBL in teaching culture is effective for the students to explore and discover the information related to their needs and interest. By asking questions to the Americans, the students can gain new and relevant knowledge related to American culture. The process is supportive for student-centered learning. Moreover, emailing the Americans provided the opportunity for students to have real-life experiences (Thomas in Kean \& Kwe, 2014). Furthermore, the students are delighted to connect with new people and extend their networking or friendship with English native speakers. Their interest to keep connecting with the Americans by doing PBL will be helpful for their personal growth to support life-long learning as language and cultural learners (Thuan, 2018). In addition, the project of emailing the Americans is helpful for the students to enhance their twentyfirst century skills to communicate, negotiate, and collaborate with their teammates in completing the project as stated by Bell (2010). Thus, the students find the project is motivating and improving their communication skills.

Referring to the principles of project work (Stoller, 2014) this project in American culture class is related to real-world topics such as education, health, leisure time, and diversity. The role of the teachers is as facilitator who connects the students with the Americans. Thus, the student-centered learning process motivates for the students to work together. On top of that, the learning process is significantly beneficial to promote the independence and analytical skills of the students as they are encouraged to find the information and to reflect to their own culture and foreign culture.

\section{CONCLUSIONS}

The finding of the research underline the effectiveness of PBL for teaching American culture for Indonesian university students. Specifically, the use of email interview is considered helpful to enhance the understanding of the students of American culture as well as promoting positive learning attitude to develop their critical and communication skills. Email interview with the Americans for PBL can be one useful alternative to deal with the challenge in teaching American culture to university students. Regarding the students' positive attitudes, PBL accommodates to promote students' active learning, independence, and collaboration as they need to cooperate well with the American that they have interviewed and worked together with their group members in creating the comprehensive presentation.

The research has also shown that students are motivated to learn American culture in authentic tasks of interviewing Americans by using PBL. Likewise, teachers and lecturers are encouraged to apply PBL in teaching foreign culture to overcome the knowledge gap and provide more connections for the students to be the global learners. Teachers can also learn from the students and the findings of their project as the source of insight in culture learning. In other words, applying PBL is truly suitable for student-centered learning.

The findings also suggest that having email interviews with English native speakers is helpful for the students to develop their target language in the integrated skills. They also improve their selfconfidence and analytical skills to organize and present the data they have collected from the textbook and email interviews the Americans. They learn how to formulate critical questions, collect the data and analyze the similarities and differences of the data they read and gain. This learning process is in accordance with the principles of PBL which promote self-reliance and engagement of the students

Despite the significant findings of the research, there are several limitations. First, the number of students is limited only to 29 students. Second, the data collection is based on the questionnaire and observation notes, and final product of the student's projects. Using various data collection such as interview or learning logs will also be useful for gaining more detailed information. Third, the length of the project is just half of the semester. Having longer duration of project evaluation is also an option for the research.

Therefore, future research is needed to gain deeper insights by investigating the opportunities and challenges of PBL in teaching American culture. This should be done by allocating longer term for doing the PBL, adding more data sources, such as face-to-face interview by using video conference and weekly learning logs related to the students' cultural understanding and attitudes after doing the interview. It will also be worth analyzing for future researcher to investigate the opportunities and challenges of PBL in teaching culture and other subjects by using various instruments such as interview, questionnaire, and learning logs as well as incorporating the use of technology for PBL in online learning.

\section{REFERENCES}

Anuyahong, B. (2015). Using project-based approach to enhance English speaking ability of Thai-Nichi Institute of Technology students. International Conference on Language, Education and Psychology (ICLEP). South Korea. pp. 67-79.

Ballantyne, S. (2016). Use of project-based learning 
approach to improve students' descriptive process writing skills. KKU International Journal of Humanities and Social Sciences, 6(3), 1-21. https:// doi.org/10.33369/joall.v1i2.4196.

Bell, S. (2010). Project-based learning for the $21^{\text {st }}$ century: Skills for the future. The Clearing House: A Journal of Educational Strategies, Issues and Ideas, 83(2), 3943. https://doi.org/10.1080/00098650903505415.

Deveci, T. (2018). Student perceptions on collaborative writing in a project-based course. Universal Journal of Educational Research, 6(4), 721-732. https://doi. org/10.13189/ujer.2018.060415.

Irawati, L. (2015). Applying cultural project based learning to develop students' academic writing. Dinamika Ilmu, 15(1), 25-32. https://doi.org/10.21093/ di.v15i1.75.

Kean, A. C., \& Kwe, N. M. (2014). Meaningful learning in the teaching of culture: The project based learning approach. Journal of Education and Training Studies, 2(2), 189-197. http://dx.doi.org/10.11114/ jets.v2i2.10.11114/jets.v2i2.227070.

Maida, C. A. (2011). Project-based learning: A critical pedagogy for the twenty-first century. Policy Futures in Education, 9(6), 759-768. https://doi.org/10.2304/ pfie.2011.9.6.759.

Mali, Y. C. G. (2016). Project-based learning in Indonesian EFL classrooms: From theory to practice. IJEE (Indonesian Journal of English Education), 3(1), 89-105. https://doi.org/10.15408/ijee.v3i1.2651.

Maryani, M., \& Aguskin, L. (2019). Incorporating Youtube clips in the classroom to develop students' cultural understanding of American culture. Lingua
Cultura, 13(4), 265-273. https://doi.org/10.21512/ lc.v13i4.5889.

Parker, J. L. (2020). Students' attitudes toward projectbased learning in an intermediate Spanish course. International Journal of Curriculum and Instruction, 12(1), 80-98. http://ijci.wcci-international.org/ index.php/IJCI/article/view/254/153.

Pratiwi, T., Marsidin, S., Syarif, H., \& Yahya, Y. (2018). Directed-project based learning as language learning model: Designing, developing and field testing. EduLite: Journal of English Education, Literature and Culture, 3(1), 40-50. https://doi. org/10.30659/e.3.1.40-50.

Stoller, F. (2014). Project work: A means to promote language and content. In Jack, C. Richards \& Willy, A. Renandya (Eds.), Methodology in Language Teaching: An anthology of Current Practice. Cambridge: Cambridge University Press.

Syzenko, A., \& Diachkova, Y. (2020). Building crosscultural competence in a foreign language through technology-enhanced project-based learning. Revista Amazonia Investiga, 9(27), 411-418. https:// doi.org/10.34069/AI/2020.27.03.45.

Thuan, P. D. (2018). Project-based learning: From theory to EFL classroom practice. Proceedings of the $6^{\text {th }}$ International Open TESOL Conference 2018. Ho Chi Minh City, Vietnam. pp. 327-339.

Utami, F. D., Tyas, M. A., \& Mustika, N. (2019). The use of commercial advertisement to teach university students in English for specific purpose context. Lingua Cultura, 13(2), 151-159. https://doi. org/10.21512/lc.v13i2.5297. 